\title{
Vibroacoustic methods of assessing valve clearance in combustion engines* An analysis of signals in the area of frequency
}

\author{
This article presents results of research referring to applying selected frequency characteristics of signal of vibration \\ accelerations of combustion engine's head to assess valve clearance of combustion engine. The authors indicate neces- \\ sity to perform preliminary preparations of signal of vibration accelerations before carrying out frequency analyses in \\ order to decrease the risk of inaccurate analysis.
}

Key words: internal combustion engines, vibroacoustic diagnostics

\section{Wibroakustyczne metody luzu zaworów silników spalinowych* Analiza sygnałów w dziedzinie częstotliwości}

\begin{abstract}
$W$ artykule przedstawiono wyniki badań dotyczace możliwości zastosowania wybranych charakterystyk częstotliwościowych sygnału przyspieszeń drgań głowicy silnika spalinowego do szacowania wartości luzu zaworów silnika spalinowego. Wskazano na konieczność wstępnego przygotowania sygnału przyspieszeń drgań, przed wykonaniem analiz częstotliwościowych, w celu zmniejszenia ryzyka błędnej diagnozy.
\end{abstract}

Słowa kluczowe: silnik spalinowy, diagnostyka wibroakustyczna

\section{Introduction}

Combustion engines are one of main drive sources of motor vehicles as well as stationary equipment. Cam unit, which operates exchange of load, is one of basic systems of self-ignition combustion engine (CI). Providing normal regulating parameters in the whole operation time, is a condition of appropriate operation of cam unit. In combustion engines, valve clearance (between valve rod and lever or between valve rod and cam) and cam phases are basic regulating parameters of the cam of combustion engine.

Valve clearance is a regulating parameter, which should be periodically checked, because incorrectly aligned valve clearance is a reason of decrease in efficiency of combustion engine operation, increase of toxic compound emission and may as well lead to damage of parts of cam unit of combustion engine e.g. partial burning of valve face and seat face of valve.

Applying automatic compensation of valve clearance enables elimination of necessity to align periodically valve clearance in combustion engines. However, putting additional masses into cam unit causes increase of inertial forces and beside this, an additional device increases possibility of failure because it is applied in series into the kinematic chain of cam unit. Out of control increase of valve clearance is a result of damage to automatic compensator of valve clearance.

The purpose of this research is to evaluate usability of selected frequency characteristics of vibration signal gener-

\footnotetext{
*) The title of a series of articles published in the journal Combustion Engines
}

\section{Wprowadzenie}

Silniki spalinowe to jedno z głównych źródeł napędu pojazdów mechanicznych oraz wielu urządzeń stacjonarnych. Jednym z podstawowych zespołów tłokowego silnika spalinowego o zapłonie samoczynnym (ZS) jest układ rozrządu, którego zadaniem jest sterowanie wymianą ładunku. Poprawne działanie układu rozrządu jest możliwe tylko wtedy, kiedy parametry regulacyjne przyjmują prawidłowe, podawane przez producenta wartości. Podstawowymi parametrami regulacyjnymi rozrządu silnika spalinowego są: luz zaworowy (między trzonkiem zaworu, a dźwignią lub między trzonkiem zaworu, a krzywką) oraz fazy rozrządu

Luz zaworów jest parametrem regulacyjnym, który należy okresowo sprawdzać, ponieważ nieprawidłowo wyregulowany luz zaworów jest przyczyną pogorszenia efektywności pracy silnika spalinowego, zwiększenia emisji związków toksycznych do atmosfery, a także może doprowadzić do uszkodzenia elementów układu rozrządu silnika spalinowego np. nadpalenie przylgni zaworów lub gniazd zaworowych. zastosowanie automatycznej kompensacji luzów zaworowych umożliwia wyeliminowanie konieczności okresowej regulacji luzu zaworów w silnikach spalinowych. Wprowadzenie do układu rozrządu dodatkowych mas powoduje zwiększenie sił bezwładności, a dodatkowe urządzenie zwiększa prawdopodobieństwo awarii, ponieważ jest włączone szeregowo w łańcuchu kinematycznym układu rozrządu. Konsekwencją uszkodzenia automatycznego kompensatora luzu zaworowego jest niekontrolowany wzrost

\footnotetext{
*) Tytuł cyklu artykułów publikowanych w czasopiśmie Combustion Engines/Silniki Spalinowe
} 
ated by combustion engine's head to assess valve clearance and to analyze the process of converting signal of vibration accelerations to receive information about the state of valve clearance.

\section{Frequency characteristics in the analysis of vibration signals}

Frequency characteristics present amplitude or signal phase in frequency function. In vibration diagnostics to assess technical condition of an object, amplitude dependence from frequency (amplitude spectrum, power spectrum, product spectrum, power spectrum density etc.) is used. On the basis of spectrum analysis identification of damaged subunit can be carried out because subunits of technical objects generate vibrations of various frequencies. Various types of analyzers are used to analyze vibration signals in the area of frequency. Spectrum analysis may be carried out with constant absolute or relative bandwidth of analysis. Spectra of vibration signals may be obtained with analog methods or with digital conversion of time histories of signals.

The analysis of signals with analog methods consists in a sequence or parallel filtration of signals with the usage of frequency band filters. Filter parameters and details of such method of converting signals are presented in works $[1,2]$.

Currently, because of dynamic development of information techniques, digital methods of converting and analyzing vibration signals are most often used. In digital methods of signal analysis, for conversion of time histories in frequency area, an expansion of function into Fourier series, in accordance with dependence (1) is used.

$$
s(t)=a_{0}+\sum_{k=1}^{\infty}\left[a_{k} \cos \left(\frac{2 \cdot \pi \cdot k \cdot t}{T}\right)+b_{k} \sin \left(\frac{2 \cdot \pi \cdot k \cdot t}{T}\right)\right]
$$

Coefficient of function expansion into Fourier series $\mathrm{a}_{0}$, $a_{k}$ and $b_{k}$ may be defined as correlation coefficient between function $\mathrm{x}(\mathrm{t})$ and a set of orthogonal basis functions by using dependencies (2), (3), and (4) $[1,4]$.

$$
\begin{gathered}
\mathrm{a}_{0}=\frac{1}{\mathrm{~T}} \int_{0}^{\mathrm{T}} \mathrm{s}(\mathrm{t}) \mathrm{dt} \\
\mathrm{a}_{\mathrm{k}}=\frac{1}{\mathrm{~T}} \int_{0}^{\mathrm{T}} \mathrm{s}(\mathrm{t}) \cdot \cos \left(\frac{2 \cdot \pi \cdot \mathrm{k} \cdot \mathrm{t}}{\mathrm{T}}\right) \mathrm{dt} \\
\mathrm{b}_{\mathrm{k}}=\frac{1}{\mathrm{~T}} \int_{0}^{\mathrm{T}} \mathrm{s}(\mathrm{t}) \cdot \sin \left(\frac{2 \cdot \pi \cdot \mathrm{k} \cdot \mathrm{t}}{\mathrm{T}}\right) \mathrm{dt}
\end{gathered}
$$

In dependencies (1) to (4) the following marks are used: $\mathrm{s}(\mathrm{t})$ - time history of signal, $\mathrm{t}$ - time, $\mathrm{T}$ - time interval, $\mathrm{k}$ - harmonic number order $(\mathrm{k}=1,2,3 \ldots), \mathrm{f}$ - frequency, $\mathrm{a}_{0}-$ signal's constant component, $\mathrm{a}_{\mathrm{k}}, \mathrm{b}_{\mathrm{k}}$ - coefficients of function expansion into Fourier series. luzu zaworów. Celem badań jest ocena przydatności wybranych charakterystyk częstotliwościowych sygnału drganiowego generowanego przez głowicę silnika spalinowego do oszacowania wartości luzu zaworów oraz analiza procesu przetwarzania sygnału przyspieszeń drgań dla pozyskania z niego informacji o stanie luzu zaworowego.

\section{Charakterystyki częstotliwościowe w analizie sygnałów drganiowych}

Charakterystyki częstotliwościowe przedstawiają amplitudę lub fazę sygnału jako funkcje częstotliwości. W diagnostyce drganiowej do oceny stanu technicznego obiektów wykorzystuje się zależność amplitudy od częstotliwości (widma amplitudowe, widma mocy, widma iloczynowe, widma gęstości mocy i inne). Na podstawie analizy widmowej można dokonać identyfikacji uszkodzonego zespołu, ponieważ zespoły obiektów technicznych generują drgania o różnych częstotliwościach. Do analizy sygnałów drgań w dziedzinie częstotliwości stosuje się różnego rodzaju analizatory. Analiza widmowa może być wykonana ze stałą bezwzględną lub względną szerokością pasma analizy. Widma sygnałów drgań można otrzymać na drodze analogowej lub cyfrowego przetwarzania przebiegów czasowych sygnału.

Analiza sygnałów metodami analogowymi polega na sekwencyjnym lub równoległym filtrowaniu sygnałów za pomocą filtrów pasmowych . Parametry filtrów oraz szczegóły tego typu przetwarzania sygnałów przedstawiono w pracach [1 i 2$]$.

$\mathrm{W}$ związku z dynamicznym rozwojem technik informatycznych, obecnie najczęściej stosuje się cyfrowe metody przetwarzania i analizy sygnałów drganiowych. W cyfrowych metodach analizy sygnałów do transformacji przebiegów czasowych w dziedzinę częstotliwości wykorzystywane jest rozwinięcie funkcji w szereg Fouriera zgodnie z zależnością (1).

Współczynniki rozwinięcia funkcji w szereg Fouriera $\mathrm{a}_{0}$, $\mathrm{a}_{\mathrm{k}}$ oraz $\mathrm{b}_{\mathrm{k}}$ można wyznaczyć jako współczynniki korelacji pomiędzy funkcją $\mathrm{x}(\mathrm{t})$, a zestawem ortogonalnych funkcji bazowych, używając zależności (2), (3), i (4) [1,4].

W zależnościach (1) do (4) zastosowano następujące oznaczenia: $\mathrm{s}(\mathrm{t})$ - przebieg czasowy sygnału, $\mathrm{t}-\mathrm{czas}, \mathrm{T}$ - przedział czasu, $\mathrm{k}$ - rząd harmonicznej $(\mathrm{k}=1,2,3 \ldots)$, $\mathrm{f}$ - częstotliwość, $\mathrm{a}_{0}$ - stała składowa sygnału, $\mathrm{a}_{\mathrm{k}}, \mathrm{b}_{\mathrm{k}}$ - współczynniki rozwinięcia funkcji w szereg Fouriera.

Warunkiem umożliwiającym przedstawienie przebiegu czasowego w postaci szeregu Fouriera jest spełnienie przez przebieg czasowy sygnału warunków Dirchleta, które sformułowano następująco [4]:

- dowolny wybrany przedział czasu $\tau$ o szerokości T można podzielić na skończoną liczbę przedziałów, w których funkcja ta jest określona, ciągła i monotoniczna,

- liczba punktów nieciągłości musi być określona, a w każdym punkcie nieciągłości istnieje granica prawo i lewostronna,

- wartość funkcji przebiegu czasowego w punkcie osobliwym jest równa średniej arytmetycznej granic. 
A condition allowing presentation of time history in a form of Fourier series is meeting by the time history of signal Dirchlet conditions, which are formulated in the following ways [4]:

- Any selected time interval $\tau$ width of T may be divided into infinite number of intervals, in which this function is definite continuous and monotone.

- Number of points of discontinuity must be definite and in each point of discontinuity a right and left limit exists.

- The value of time history function in singular point equals arithmetic mean of the limits.

It was stated in paper [4] that each vibroacoustic signal meets Dirchlet conditions.

Coefficients ak and bk are complex spectrum of signal. Amplitude spectrum is described with equation (5) and frequency spectrum can be determined on the basis of dependence (6).

$$
\begin{aligned}
& A(k)=\sqrt{a_{k}^{2}+b_{k}^{2}} \\
& \theta(k)=\operatorname{arctg}\left(\frac{b_{k}}{a_{k}}\right)
\end{aligned}
$$

where: $\mathrm{A}(\mathrm{k})$ means amplitude spectrum, $\theta(\mathrm{k})$ means frequency spectrum, $\mathrm{k}$ means harmonic number order $(\mathrm{k}=1$, $2,3 \ldots), a_{k}, b_{k}$ mean coefficients of function expansion into Fourier series.

\section{Methodology and research object}

For the research a testing combustion engine ZS type SB 3.1 was used. During the research the following parameters of engine's work were taken: motor speed of $700 \mathrm{rpm}$, motor torque without load (approx. $3 \mathrm{~N} \cdot \mathrm{m}$ brake's self-resistances) and cooling liquid temperature of $75^{\circ} \mathrm{C}$.

The research was carried out in accordance with principles of active experiment. The value of clearance between valve stem and valve lever was changed, and at the same time, changes of values of point parameters of speed signals and vibration accelerations were observed. Valve clearance was changed in the range of $0.3 \div 1 \mathrm{~mm}$ with step $0.1 \mathrm{~mm}$.

Acceleration signals and vibration velocity of vibration signals in three reciprocally orthogonal directions, pressure signal in cylinder and signal from angle marker of crankshaft revolution, were registered. To acquire the time histories of mentioned values a system PULSE B\&K $3560 \mathrm{C}$ with triaxial piezoelectric vibration converter, piezoelectric pressure converter and angle marker of crankshaft, was used. Detailed assumptions are presented in papers $[3,5,6]$.

\section{Analysis of selected research results}

A package of Matlab software with Signal Processing was used to convert signals of vibration accelerations. Signals of vibration accelerations in parallel direction to crankshaft's axle were analyzed, because parameters measured in this direction enabled unique determination of the value of valve clearance. Before defining frequency characteristics, the signals were subject of preliminary processing consist-
W pracach [4] stwierdzono, że każdy sygnał wibroakustyczny spełnia warunki Dirchleta.

Współczynniki $a_{k}$ i $b_{k}$ są widmem zespolonym sygnału. Widmo amplitudowe opisuje równanie (5), natomiast widmo fazowe można wyznaczyć na podstawie zależności (6). gdzie: $\mathrm{A}(\mathrm{k})$ - widmo amplitudowe, $\theta(\mathrm{k})$ - widmo fazowe, $\mathrm{k}$ - rząd harmonicznej $(\mathrm{k}=1,2,3 \ldots), \mathrm{a}_{\mathrm{k}}, \mathrm{b}_{\mathrm{k}}$ - współczynniki rozwinięcia funkcji w szereg Fouriera.

\section{Metodyka i obiekt badań}

Do badań użyto badawczego silnika spalinowego o ZS typu SB 3.1. W trakcie badań przyjęto następujące parametry pracy silnika: prędkość obrotowa $700 \mathrm{obr} / \mathrm{min}$, moment obrotowy bez obciążenia (ok. $3 \mathrm{~N} \cdot \mathrm{m}$ - opory własne hamulca), temperatura cieczy chłodzącej $75^{\circ} \mathrm{C}$.

Badania zostały przeprowadzone zgodnie z zasadami eksperymentu czynnego. Zmieniano wartość luzu zaworów pomiędzy trzonkiem zaworów a dźwignią zaworową w zakresie $0,3-1 \mathrm{~mm}$ z krokiem $0,1 \mathrm{~mm}$ i równocześnie obserwowano zmiany zachodzące $\mathrm{w}$ widmach amplitudowych, wyznaczonych z sygnałów prędkości i przyspieszeń drgań.

Zarejestrowano sygnały przyspieszeń oraz prędkości drgań w trzech wzajemnie prostopadłych kierunkach, sygnał ciśnienia panującego w cylindrze oraz sygnał ze znacznika kąta obrotu wału korbowego. Do akwizycji przebiegów czasowych wymienionych wielkości użyto systemu PULSE B\&K $3560 \mathrm{C}$ wraz z trójosiowym piezoelektrycznym przetwornikiem drgań, piezoelektrycznym przetwornikiem ciśnienia znacznikiem kąta obrotu wału korbowego. Szczegółowe założenia zastosowanej metodyki badań przedstawiono w pracach $[3,5,6]$.

\section{Analiza wyników badań}

Do przetwarzania sygnałów przyspieszeń drgań wykorzystano pakiet programu Matlab z dodatkiem Signal Processing. Analizie poddano sygnały przyspieszeń drgań w kierunku równoległym do osi wału korbowego, ponieważ mierzone parametry $\mathrm{w}$ tym kierunku umożliwiały jednoznaczne określenie wartości luzu zaworowego. Przed wyznaczeniem charakterystyk częstotliwościowych, sygnały poddano wstępnej obróbce polegającej na selekcji czasowej [2]. Oznacza to, że w obliczeniach uwzględniono tylko te odcinki przebiegów czasowych przyspieszeń drgań, które czasowo były związane z momentem zamykania zaworów. Operacja selekcji czasowej była konieczna, ponieważ bez jej zastosowania obliczone miary punktowe sygnałów przyspieszeń drgań wyznaczone na podstawie widm charakteryzowały się niewystarczającą dynamiką zmian w funkcji luzu zaworowego (do celów diagnostycznych). Na podstawie tak przygotowanego sygnału wyznaczono widma amplitudowe, które następnie uśredniono.

Na rysunku 1 przedstawiono zmiany postaci widma amplitudowego przyspieszeń drgań od luzu zaworów rozrządu silnika spalinowego. Analiza postaci widm amplitudowych sygnału przyspieszeń drgań wykazała, że największą wrażliwość na zmianę luzu zaworów wykazuje zmiana wartości 


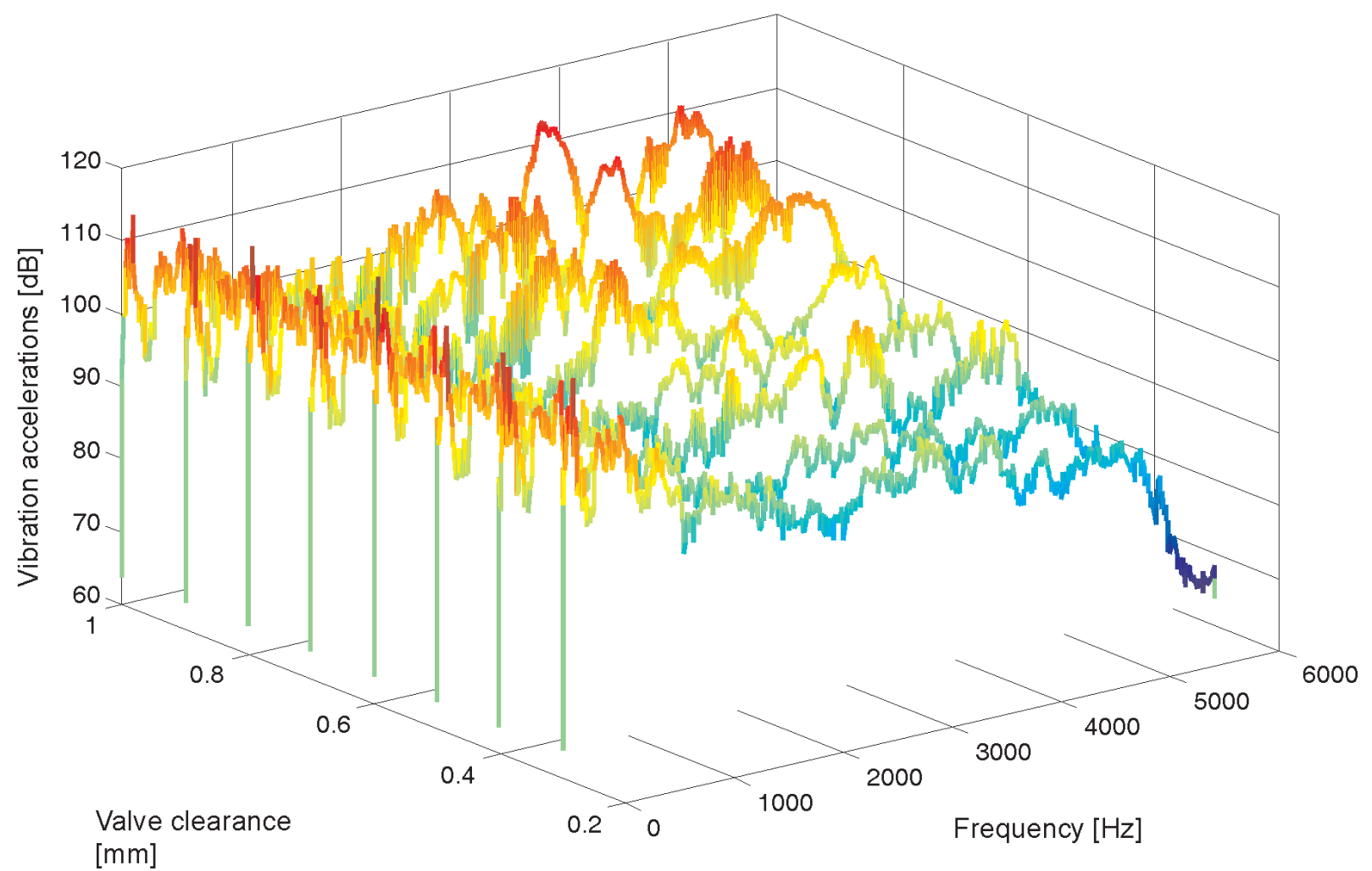

Fig. 1. Dependence of amplitude spectrum form of vibration accelerations from valve clearance of combustion engine type SB 3.1

Rys. 1. Zależność postaci widma amplitudowego przyspieszeń drgań od luzu zaworów silnika spalinowego SB 3.1

ing in time selection [2]. This means that in calculations only the intervals of time history of vibration accelerations, which temporarily were connected with the moment of valve closing, were taken into account. The operation of time selection was necessary because without applying it, calculated point parameters of signals of vibration accelerations defined on the basis of spectra had been characterized by insufficient for diagnostics purposes, dynamics of changes in the function of valve clearance. On the basis of signal prepared in the described way, amplitude spectra were defined and then averaged.

Figure 1 presents changes of amplitude spectrum of vibration accelerations from valve clearance of calm unit of combustion engine. The skutecznych przyspieszeń drgań w paśmie 4500-5500 Hz. Na rysunku 2 przedstawiono zmiany postaci widm amplitudowych wykonanych po filtracji pasmowej w zakresie częstotliwości 4500-5500 Hz.

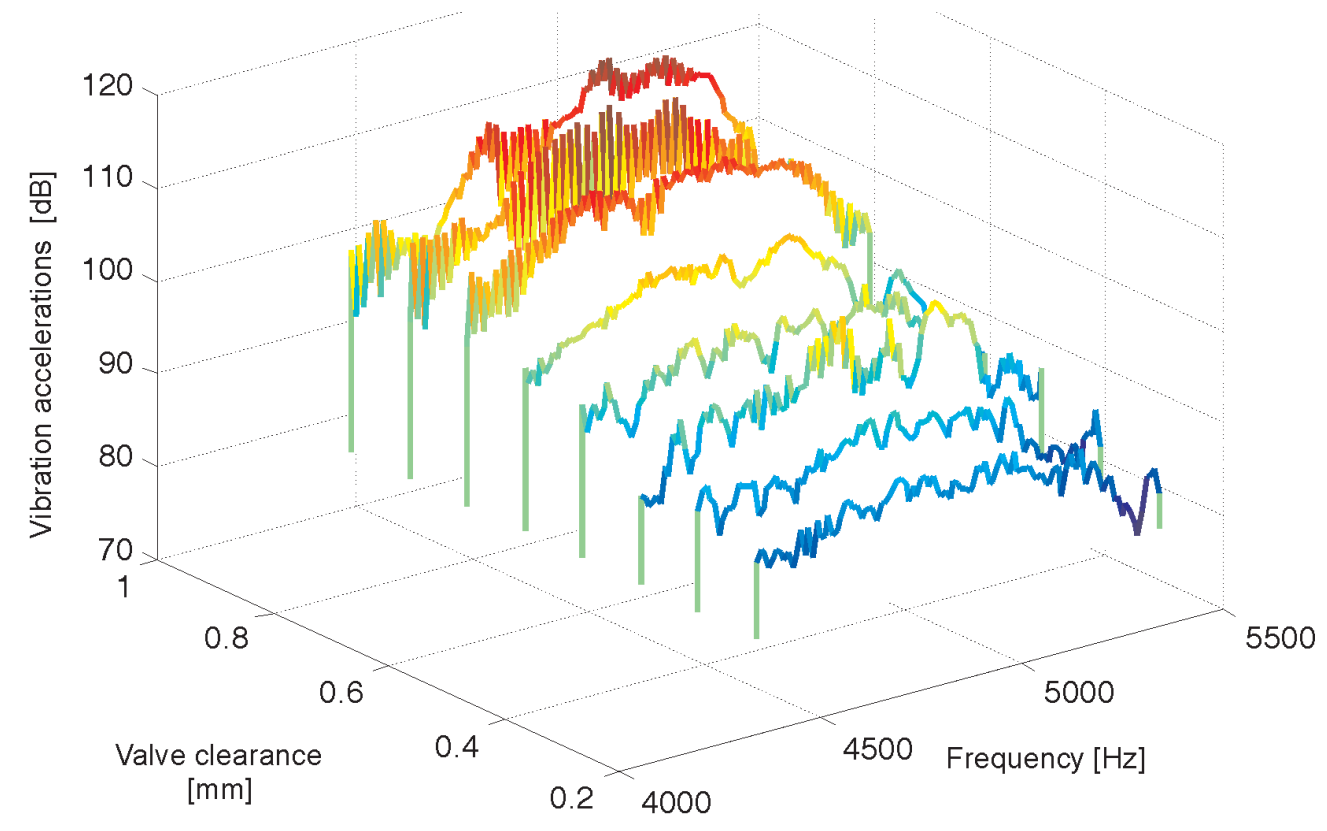

Fig. 2. Dependence of amplitude spectrum form of vibration accelerations in frequency $4500-5500 \mathrm{~Hz}$ from valve clearance of combustion engine type SB 3.1

Rys. 2. Zależność postaci widma amplitudowego przyspieszeń drgań w paśmie 4500-5500 Hz od luzu zaworów silnika spalinowego $S B 3.1$ 
analysis of amplitude spectra form of vibration signals pointed out that the change of effective values of vibration accelerations within frequency 4500-5500 $\mathrm{Hz}$ show the best connection with changes in valve clearance. Figure 2 presents changes in amplitude spacra form carried out after frequency filtration within frequency $4500-5500 \mathrm{~Hz}$.

Figure 3 presents dependence of effective value of vibration accelerations in frequency 4500 $5500 \mathrm{~Hz}$ from valve clearance of combustion engine, which was approximated (with the methode of least squares) with a linear function. As a result of the approximation the equation of curve (7) was obtained, which is graphically presented in Fig. 3.

$\mathrm{a}_{\mathrm{x} R M S}=25.35 \cdot \mathrm{L}_{\mathrm{z}}+87.81(7)$

The value of correlation coefficient between measurement results and the calculation results using dependence (7) equaled 0.98 . This means very good representation of real measurements in mathematical model

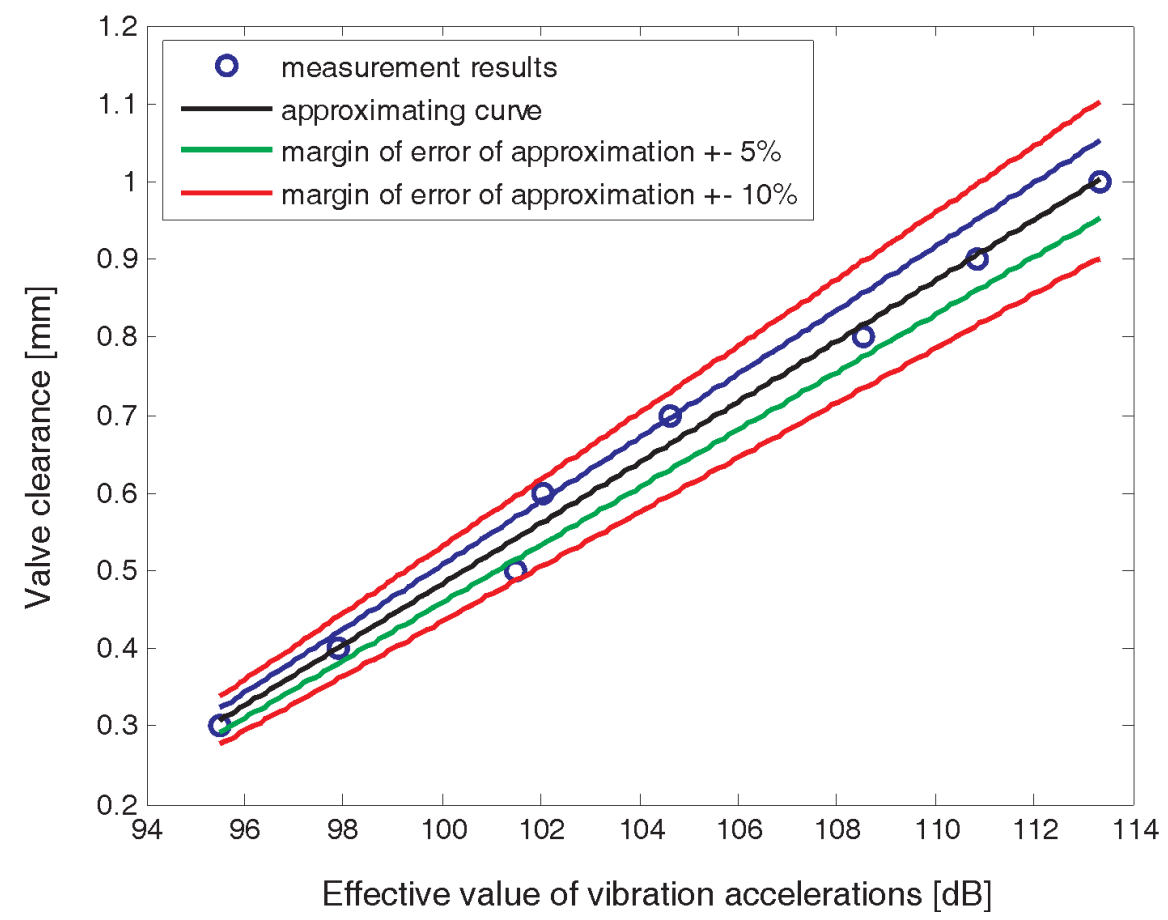

Fig. 4. Dependence of valve clearance of combustion engine SB 3.1 from effective value of vibration accelerations in frequency $4500-5500 \mathrm{~Hz}$

Rys. 4. Zależność luzu zaworów silnika spalinowego SB 3.1 od wartości skutecznej przyspieszeń drgań w paśmie 4500-5500 Hz

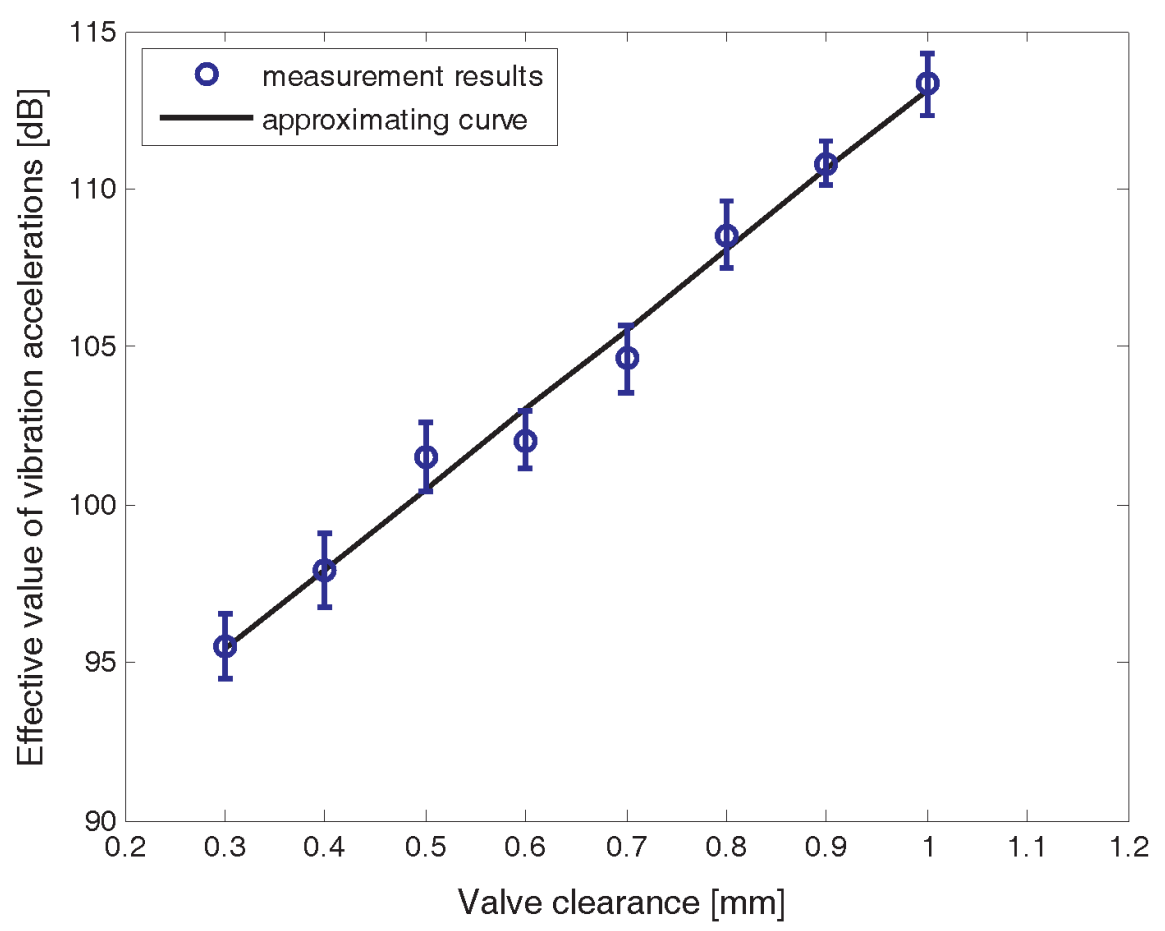

Fig. 3. Dependence of effective value of vibration accelerations in frequency $4500-5500 \mathrm{~Hz}$ from valve clearance of combustion engine type SB 3.1

Rys. 3. Zależność wartości skutecznej przyspieszeń drgań w paśmie 4500-5500 Hz od luzu zaworów silnika spalinowego $S B 3.1$

Na rysunku 3 przedstawiono zależność poziomu skutecznej wartości przyspieszeń drgań w paśmie 4500-5500 Hz, od luzu zaworów silnika spalinowego, którą aproksymowano (metodą najmniejszych kwadratów) funkcją liniową. W wyniku aproksymacji otrzymano równanie prostej (7), którego graficzną reprezentację zaznaczono na rysunku 3.

Wartość współczynnika korelacji pomiędzy wynikami pomiarów a wartościami uzyskanymi z obliczeń, wykorzystując zależność (7), wyniosła 0,98. Oznacza to bardzo dobre odwzorowanie rzeczywistych pomiarów w modelu matematycznym, opisującym zmiany luzu zaworów w zależności od skutecznej wartości przyspieszeń drgań, natomiast dynamika zmian parametru diagnostycznego wyniosła aż $17 \mathrm{~dB}$.

Podstawowym celem badań diagnostycznych jest określenie luzu zaworów na podstawie znanej skutecznej wartości przyspieszeń drgań. W tym celu przeprowadzono obliczenia w oparciu o krzywą aproksymującą. W równaniu za zmienną objaśniająca przyjęto wartość skuteczną przyspieszeń drgań, 
describing changes of valve clearance depending on effective value of vibration accelerations, whereas the dynamics of changes in diagnostic parameter equaled $17 \mathrm{~dB}$.

The main purpose of diagnostic tests is to determine valve clearance on the basis of known effective value of vibration accelerations. For this purpose calculations based on approximating curve were carried out. In the equation an effective value of vibration accelerations was taken as explaining variable, and valve clearance was taken as explained variable. As a result of calculating approximation coefficients, a curve described with dependency (8) was obtained, which is described in Fig. 4,

$$
\mathrm{L}_{\mathrm{z}}=0.039 \cdot \mathrm{a}_{\mathrm{x} \text { RMS }}-3.416
$$

where: $a_{x \text { RMS }}$ means level of effective value of vibration accelerations $[\mathrm{dB}], \mathrm{Lz}$ means valve clearance $[\mathrm{mm}]$.

\section{Conclusion}

This paper presents analysis of possibilities of applying amplitude spectrum to assess valve clearance of calm unit. On the basis of carried out research and the analysis of signal of vibration accelerations it was stated that spectrum frequency $4.5-5.5 \mathrm{kHz}$ shows the greatest changes in dependency form the value of valve clearance for the tested engine. Effective values of vibration accelerations defined within this frequency are characterized by big dynamics of changes that equals $17 \mathrm{~dB}$. Applying levels of vibration accelerations for regression calculation enabled using equation of a straight line for approximation, which significantly enables to simplify the procedure of assessing valve clearance on the basis of parameters of vibration signal. It was also found out that the condition to obtain satisfactory accuracy of assessing valve clearance on the basis of frequency analysis of vibration signals is making time series subject of preliminary processing consisting in time separation. Further research concerning possibility to assess valve clearance will refer to issues connected with applying time-frequency analysis to assess valve clearance in piston combustion engine.

This work was financed from science resources for years 2008 2011 as research project $\mathrm{Nr} N \mathrm{~N} 502463034$

Paper reviewed/Artykut recenzowany

Prof. Franciszek Tomaszewski, DSc., DEng. - Professor in the Faculty of Working Machines and Transportation at Poznan University of Technology.

Dr hab. inż. Franciszek Tomaszewski - profesor na Wydziale Maszyn Roboczych i Transportu Politechniki Poznańskiej.

e-mail: franciszek.tomaszewski@put.poznan.pl a za zmienną objaśnianą luz zaworów. W wyniku obliczeń współczynników aproksymacji otrzymano krzywą opisaną zależnością (8), przedstawioną na rysunku 4,

gdzie: $a_{x \text { RMS }}$ - poziom wartości skutecznej przyspieszeń drgań $[\mathrm{dB}], \mathrm{L}_{\mathrm{z}}$ - luz zaworów [mm].

\section{Podsumowanie}

W pracy przedstawiono analizę możliwości zastosowania widma amplitudowego do oszacowania wartości luzu zaworów układu rozrządu. W oparciu o przeprowadzone badania i analizę sygnału przyspieszeń drgań stwierdzono, że pasmo widma 4,5-5,5 kHz wykazuje największe zmiany w zależności od wartości luzu zaworowego dla badanego silnika. Wyznaczone w tym paśmie wartości skuteczne przyspieszeń drgań cechuje duża dynamika zmian wynosząca $17 \mathrm{~dB}$. Zastosowanie do obliczeń regresyjnych poziomów przyspieszeń drgań pozwoliło zastosować do aproksymacji równanie prostej, co w znaczący sposób pozwala uprościć procedurę szacowania luzu zaworowego na podstawie parametrów sygnału drganiowego. Stwierdzono ponadto, że warunkiem uzyskania zadowalającej dokładności oszacowania luzu zaworów na podstawie analizy częstotliwościowej sygnałów drganiowych jest poddanie szeregów czasowych wstępnemu przetwarzaniu, polegającemu na zastosowaniu separacji czasowej. Dalsze prace dotyczące oceny luzu zaworów będą dotyczyły zagadnień związanych z zastosowaniem analizy czasowo-częstotliwościowej do oceny luzu zaworów tłokowego silnika spalinowego.

Praca naukowa finansowana ze środków na naukę w latach 2008-2011 jako projekt badawczy Nr N N 502463034

\section{Bibliography/Literatura}

[1] Randall R.B., Tech B.A.: Frequency analisis. Brüel \& Kjær 1987.

[2] Cempel Cz.: Podstawy wibroakustycznej diagnostyki maszyn. Wydawnictwa Naukowo-Techniczne Warszawa 1982.

[3] Czechyra B., Szymański G., Tomaszewski F.: Ocena luzu zaworów silnika spalinowego w oparciu o parametry drgań założenia metodyczne. Silniki Spalinowe nr 1/2004(118).

[4] Fichtenholtz G.M.: Rachunek różniczkowy i całkowy III. PWN Warszawa 1985.

[5] Szymański G.: Ocena stanu regulacji zaworów silnika spalinowego za pomocą sygnału drganiowego. Praca magisterska. Politechnika Poznańska, Poznań 2000.

[6] Szymański G.: Analiza możliwości zastosowania wybranych charakterystyk sygnału drganiowego do diagnostyki silnika spalinowego. Rozprawa doktorska, Politechnika Poznańska, Poznań 2005.

Mr. Grzegorz M. Szymański, DEng. - doctor in the Faculty of Working Machines and Transportation at Poznan University of Technology.

Dr inż. Grzegorz M. Szymański - adiunkt na Wydziale Maszyn Roboczych i Transportu Politechniki Poznańskiej.

e-mail: grzegorz.m.szymanski@put.poznan.pl

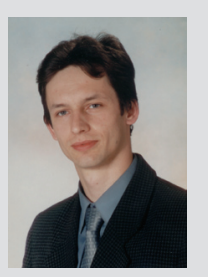

